\title{
The vegetation composition, structure and regeneration status of Gole Natural Forest, West Arsi Zone, Oromia Regional State, Ethiopia.
}

\author{
Mesfin Belete Hailemariam*, Tamiru Demsis Temam \\ Wolkite University, Gubrei, Wabe Bridge, Ethiopia
}

\begin{abstract}
This study was conducted in Gole natural forest (Dodola) West Arsi Zone of Oromia Regional State, Ethiopia. The study was intended to investigate the vegetation composition, structure, community types and the regeneration status. To collect the vegetation data, systematically 62 plots $20 \mathrm{~m} \times 20 \mathrm{~m}\left(400 \mathrm{~m}^{2}\right)$ were established at $100 \mathrm{~m}$ interval, starting from the top of the mountain. Tree and shrub species were counted and their cover abundance value was estimated. The data for herbaceous species were collected from five $2 \mathrm{~m} \times \mathbf{2} \mathrm{m}$ sub-plots laid at the four corners each and one at the centre of the main plot. Height and diameter at breast height (DBH) of all woody species taller than $1.5 \mathrm{~m}$ and thicker than $2 \mathrm{~cm}$ were measured. $R$ package was applied for cluster analysis. Indicator species analysis was performed in $\mathbf{R}$ Interpolated species accumulation curves. Estimate $S \mathbf{8 . 2}$ Software and Microsoft Excel were used to analyze the data. Rarefaction was applied to compare the species richness of the plant communities in the study area. Sorensen's similarity coefficient was used to detect similarities and dissimilarities among communities.

A total of 114 plant species belonging to 57 families and 94 genera were identified. The most dominant families were Asteraceae, followed by Acanthaceae and Lamiaceaae. Out of 114 species 17 were endemic to Ethiopia. The study showed that high density was seen at lower height and DBH classes. Five plant community types were identified. The rarefaction revealed that there is difference in species richness among communities. The Sorensen's similarity index showed that, there was a difference in the distribution of plant species composition among the five plant communities.
\end{abstract}

Keywords: Afromontane forest, Gole forest, Rarefaction, Sorensen's similarity

Endemic species, Seedlings, Saplings, Population structure, Importance value index.

Accepted April 20, 2018

\section{Introduction}

Mountain ecosystems around the globe are known for their high biological diversity and usually have distinct biological communities and high level of endemism, due to their topography [1]. Forest provides a wide range of ecological, economical, social and cultural services and processes [2]. Forests regulate water regimes/as water catchments, cultural and aesthetic services and provide ecosystem services, including nutrient cycling, soil formation, oxygen production, carbon sequestration and prevention of air pollution [3-5]. Mountain forests have a high potential for securing livelihoods by providing non-timber forest products $[5,6]$. They also used locally to generate income and in traditional foods and medicine $[3,5]$.

Ethiopia has great biodiversity resources due to the diversity in physical features, climate, topography, habitat, vegetation types and fauna [7]. Altitudes range from 126 meters below sea level in the Dalol (Afar) depression, to the highest mountain, Ras Dejen in the Semen Mountains 4,620 meters above sea level [8]. In Ethiopia, environmental degradation and deforestation have been taking place for hundreds of years. Forests in the entire country declined from the original $35 \%$ to $16 \%$ in 1952 , $3.6 \%$ by $1980,2.6 \%$ by 1987 , and an estimated $2.4 \%$ in 1992 [9]. The major threats to the bio diversities are unsustainable utilization of natural resources, deforestation, conversion of natural vegetation to farmland, alien invasive species, climate change and lack of proper policy framework [4,10,11]. This remnant stands of natural forests are found in remote and inaccessible part of the country [12]. Therefore, the recognition of these threats to biodiversity has led to draw conservation strategies to protect from the threats. Thus, availability of accurate data on forest resources is an essential requirement for forest management and planning within the context of sustainable development. Various attempts have been made to study the forests in different parts of the country. Gole natural forest is highly valued for its socio-economic and ecological services. However, the assessment of vegetation composition, structure, distribution and other attributes has not been studied so far in the study area. Therefore, the present study attempts to provide information on the vegetation composition, structure and regeneration status of Gole forest.

\section{Objectives of the Study}

\section{General objective}

The general objective of this study is to investigate the vegetation of Gole natural forest which could serve as an important input for conservation of the forest in the study area. 
Citation: Hailemariam MB, Temam TD. The vegetation composition, structure and regeneration status of Gole Natural Forest, West Arsi Zone, Oromia Regional State, Ethiopia. J Agric Sci Bot. 2018;2(2):10-21.

\section{Specific objectives}

$\bullet$

- to analyze the vegetation structure and tree species population structure of Gole forest

- to identify main plant community types in Gole forest

- to investigate the regeneration status of woody species in Gole forest

- to investigate the similarity of Gole Forest with some other forests in Ethiopia regarding its composition.

\section{Research questions}

In order to realize the above mentioned research objectives, the following research questions should be answered in the course of this study:

- What plant species are common in Gole forest?

- What the vegetation structure of Gole forest looks like?

- What are the main plant community types in Gole forest?

- Does Gole Forest is similarity with other forests in Ethiopia?

- What does the regeneration status of main woody plants in Gole forest looks like?

\section{Materials and Methods}

\section{Location of the study area}

The Gole natural forest is found in Dodola woreda, West Arsi Zone of Oromia Regional state, Ethiopia. It is located in the south-east part of the country $320 \mathrm{~km}$ away from the capital city Addis Ababa. The study area is found between latitude $6^{0} 51$, and $6^{\circ} 53^{\prime} \mathrm{N}$ and longitude $39^{\circ} 11^{\prime}$ and $39^{\circ} 12^{\prime} \mathrm{E}$, east of Dodola town in Deneba kebele. The altitudinal range of the study area is between 2728-3480 m a.s.l (Figure 1).

\section{Climatic conditions}

Rainfall is bimodal distribution, with the main rainy season occurring between June to September. The dry season lasts from November to February, followed by short rainy season during the months of March and April [13]. There is no metrological station in the study area but the climatic data for the Dodola town recorded by Agricultural shows that, the area has a mean annual rainfall of $733 \mathrm{~mm}$ and the temperature ranges from $7-24^{\circ} \mathrm{C}[14]$.

\section{Vegetation}

The vegetation of the study area mainly falls in to the Dryevergreen afromontane forest $(1600-3300 \mathrm{~m})$ and the subafroalpine $(3200-3500 \mathrm{~m})$ vegetation type $[3,15]$. The forest formation changes along the altitudinal gradient. At the altitude between 2,850-3,000 $\mathrm{m}$ a.s.1., Juniperus procera is dominant in association with few Podocarpus falcatus. At the upper zone between 3,000-3,400 m a.s.l., Hagenia abyssinica, Hypericum revolutum and Erica arborea dominate the forest, sometimes mixed with Juniperus procera. Erica arborea occurs as a shrub at its uppermost distribution [16].

\section{Socio-Economic conditions}

The human population of the study area was estimated to be 237610 (117494 were male and 120116 were female) of which 27812 (14693 male and 13119 female) were living in the district capital of Dodola [17]. The farming systems are mainly characterized by the presence of subsistence mixed farming, of both livestock and agricultural crop production. There are also many households engaged in collecting and selling forest products. Forest is the main source of fuel wood demand for the whole communities. The forest is just on converting into

\section{Vegetation data sampling methods}

Systematically, plots of $20 \mathrm{~m} \mathrm{x} 20 \mathrm{~m}\left(400 \mathrm{~m}^{2}\right)$ were established at every $100 \mathrm{~m}$ interval between the plots, starting from the top of the mountain to the lower side. A total of 62 plots were laid for vegetation data collection. For tree and shrub assessment, the $400 \mathrm{~m}^{2}$ plots were sampled. For the collection of herbaceous

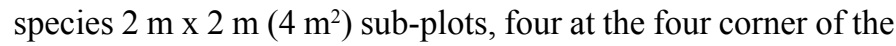
main plote and one at the center was laid [18].

From each plot, local name (if the local name was not known code of voucher specimen) and voucher specimen for all plants were collected. Abundance and cover-abundance of trees, shrubs, liana and abundance of herbaceous plants were

\section{My Study Map in W/Aris Zone at Dodola Woreda}

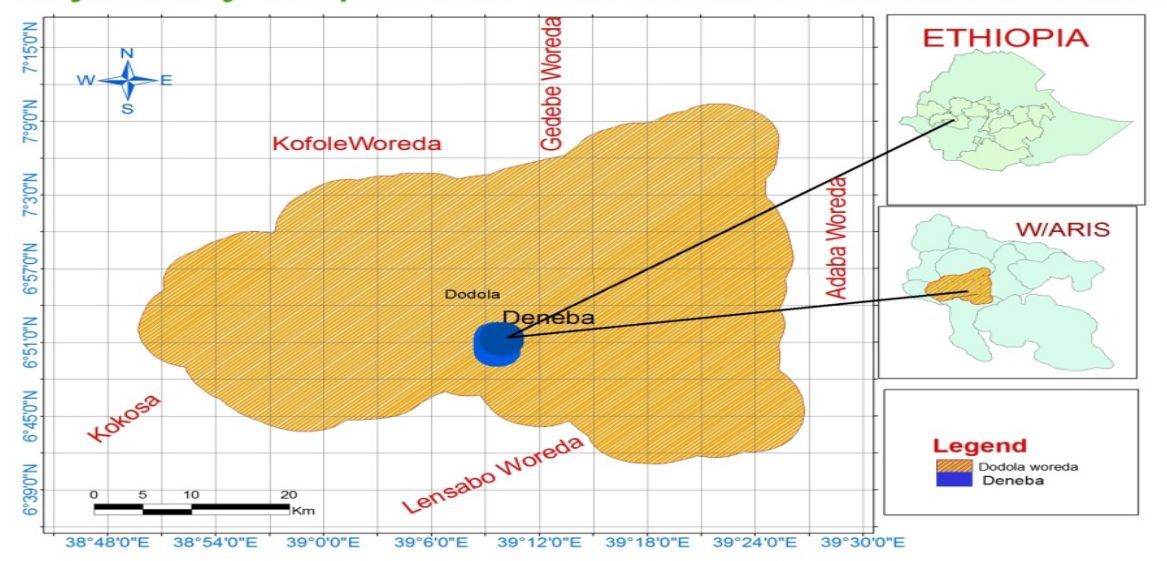

Figure 1. Location Map of the Study area (Gole Forest). 
recorded. Height and Diameter at breast height (at $1.30 \mathrm{~m}$ above ground) of each woody species having $\mathrm{DBH}>2 \mathrm{~cm}$ and height of each woody species higher than $1.5 \mathrm{~m}$ were recorded. Tree height was measured using Suunto clinometers and meter tape and diameter at breast height measured using meter tape, this measurement was obtained from circumference $(d=c / \pi)$. Coverabundance values were estimated following

Braun-Blanquette scale and converted into [19,20]. All plant specimens in the plots were recorded and voucher specimens were pressed and dried. Voucher specimens were

at National Herbarium of Addis Ababa University Ethiopia. The nomenclature of the plants was based on the published volumes of the Flora of Ethiopia and Eritrea [21-27]. The number of seedlings and saplings were collected to determine the regeneration status of the forest.

\section{Data Analysis}

All tree, shrub and herbaceous species recorded in all plots were used in the analysis of the vegetation structure. The percentages of various plant families, DBH and height classes of woody plants in the study area were summarized in pi-chart and bar graphs. Dominance curve was used to rank the relative abundance of the species The vertical structure of tree species was described following the International Union Forestry Research Organization (IUFRO) scheme [28]. Seedlings (height less than $1.5 \mathrm{~m}$ ) and saplings (height between 1.5-3 m) were considered as sapling [29], and measured using the meter tape to estimate the regeneration status of the forest.

and $\lceil$ ordination methods were used to describe vegetation types and to examine the relationship between vegetation types and environmental variables. $\mathrm{R}$ statistical package [30] was used for cluster and ordination analysis. Indicator species analysis was performed to indicator species characterizing the communities. Indicator species analysis was performed in $\mathrm{R}$ using package labdsv [31]. Interpolated species accumulation curves were used to display the expected number of species in each community type as a function of accumulated number of plots. Estimate S 8.2 software [32] was used to compute the expected species richness and species richness estimators. Sorenson's index was computed to assess the similarity between the plant communities of the study area. Sorenson's index of similarity (Ss) was computed to assess the similarity between the communities and to compare the association of Gole forest with other forests in Ethiopia.

\section{Results and Discussion}

\section{Floristic composition}

A total of 114 species of vascular plants, belonging to 94 genera and 57 families were recorded from 62 plots laid in the forest (Appendix I). The families with the highest number of species were Asteraceae, represented by 21 species (18.42\%) belonging to 14 genera, followed by Acanthaceae ( 5 species) belonging to 5 genera, Lamiaceae ( 5 species) belonging to 4 genera and Rosaceae (5 species) belonging to 4 genera $13.17 \%(4.39 \%$ each). The remaining families were represented by one or two species.

\section{Growth forms}

The collected species were composed of $25(21.9 \%)$ trees, 27 (23.7\%) shrubs, 43 (37.7\%) herbs, 11 (9.6\%) climbers, $6(5.3 \%)$ grass and $2(1.8 \%)$ fern. Herbs occupied the highest composition followed by shrubs and trees. Trees and shrubs

\section{Plant endemism in gole natural forest}

Among the species collected, 17 plant species have been recorded to be endemic to Ethiopia. Herbs, shrubs and climbers constitute $58.82 \%, 35.29 \%$, and $5.88 \%$ respectively. The presence of these endemic species in the forest shows the importance of the conservation process of the forest (Table 1) [33,34].

The density of selected plant species (Table 2).

The above table shows some of the most abundant tree, shrub, climber and herbaceous species in the study area.

\section{DBH-Class distribution}

A total of 2236 individuals whose $\mathrm{DBH}>2 \mathrm{~cm}$ were recorded and seven DBH classes were established for DBH analysis. DBH class1 (2-5), 2(5.01-20), 3(20.01-40), 4(40.01-60), 5(60.01-800, $6(80.01-100)$ and 7 (>100).

\section{Habit}

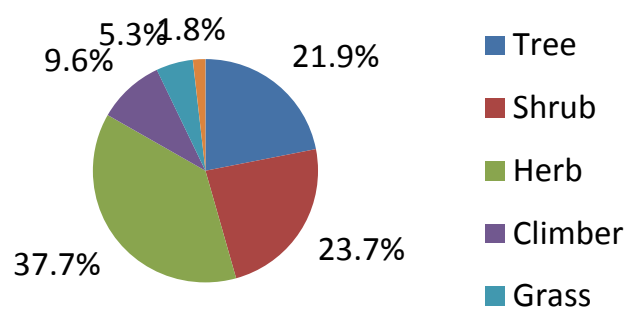

Figure 2. The growth form of collected plant species.

Table 1. Endemic plant species occurring in Gole forest.

\begin{tabular}{|c|c|c|c|c|}
\hline No & Scientific Name & Family & Habit & $\begin{array}{c}\text { IUCN } \\
\text { Category }\end{array}$ \\
\hline 1 & Acanthus senii & Acanthaceae & Sh & NT \\
\hline 2 & Bidens pachyloma & Asteraceae & H & LC \\
\hline 3 & Conyza spinosa & Asteraceae & Sh & \\
\hline 4 & Echinops ellenbekii & Asteraceae & Sh & EN \\
\hline 5 & Echinops longisetus & Asteraceae & H & LC \\
\hline 6 & Inula conifertiflora & Asteraceae & Sh & NT \\
\hline 7 & Kalanchoe petitiana & Krassulaceae & H & LC \\
\hline 8 & Kniphofia foliosa & Asphodelaceae & H & \\
\hline 9 & Mikaniopsis clematoides & Asteraceae & C & LC \\
\hline 10 & Mytenus addat & Celastraceae & Sh & NT \\
\hline 11 & Sedum mooneyi & Crassulacea & H & \\
\hline 12 & Senecio fresenii & Asteraceae & H & \\
\hline 13 & Senecio myriocephalus & Asteraceae & H & LC \\
\hline 14 & Solanecio gigas & Asteraceae & Sh & LC \\
\hline 15 & Thymus schimperi & Lamiaceae & H & LC \\
\hline 16 & Trifolium calocephalum & Fabaceae & H & \\
\hline 17 & Urtica simensis & Urticaceae & H & LC \\
\hline
\end{tabular}

Key: $L C=$ Least Concern $; N T=$ near threatened EN=endangered; IUCN = International Union for the Conservation of Nature and Natural Resources. 
Citation: Hailemariam MB, Temam TD. The vegetation composition, structure and regeneration status of Gole Natural Forest, West Arsi Zone, Oromia Regional State, Ethiopia. J Agric Sci Bot. 2018;2(2):10-21.

Table 2. The most abundant plant species in Gole forest.

\begin{tabular}{|c|c|c|c|}
\hline Species & Habit & Density/ha & $\%$ \\
\hline Juniperus procera & Tree & 284.7 & 28 \\
\hline Myrsine melanophloeos & Tree & 218.5 & 21.5 \\
\hline Hypericum revolutum & Tree & 111.3 & 10.9 \\
\hline Podocarpus falcatus & Tree & 95.6 & 9.4 \\
\hline Erica arborea & Tree & 97.2 & 9.6 \\
\hline Mytenus arbutifolia & Tree & 54.4 & 5.4 \\
\hline Myrisine africana & Shrub & 75.4 & 13.5 \\
\hline Discopodium penninervum & Shrub & 70.6 & 12.6 \\
\hline Rubus apetalus & Shrub & 63.7 & 11.4 \\
\hline Inula conifertiflora & Shrub & 58.9 & 10.5 \\
\hline Dovyalis abyssinica & Shrub & 55.6 & 10 \\
\hline Mikaniopsis clematoides & Climber & 81 & 33 \\
\hline Aspargus africanus & Climber & 49.6 & 20.2 \\
\hline Caucanthus auriculatus & Climber & 39.9 & 16.2 \\
\hline Ipomoea involucrate & Climber & 15.7 & 6.4 \\
\hline Clematis hirsuta & Climber & 13.7 & 5.6 \\
\hline Pterolobium stellantum & Climber & 13.3 & 5.4 \\
\hline Helichrysum formosissmum & Herb & 219.9 & 11.9 \\
\hline Kniphofia foliosa & Herb & 170.6 & 9.6 \\
\hline Haplocarpha schimperi & Herb & 160.5 & 9.1 \\
\hline Kalanchoe petitiana & Herb & 152 & 8.6 \\
\hline Myosotis abyssinica & Herb & 141.1 & 7.9 \\
\hline Minulopsis solmisii & Herb & 108.9 & 6.1 \\
\hline
\end{tabular}

The total number of woody species in each DBH class decreased with increasing DBH. The highest density of the populations, $864(38.6 \%)$, were found in the lower DBH class $(2-5 \mathrm{~cm})$, while the rest $367(16.4 \%), 324(14.5 \%), 281(12.6 \%), 218$ (9.7\%), $117(5.2 \%)$, and 65(2.9\%), were found between $\mathrm{DBH}$ classes 2-7 respectively. This was a normal DBH distribution pattern when viewed from the whole set of plant community, reversed J shape. They exhibited good reproduction and recruitment. But there would be variation when individual species was analyzed separately (Figure 3 ).

The DBH-class distribution of individual tree species having higher important value index was described below to see the likely future of these trees.

The DBH measurements of Juniperus procera (Figure 4A) shows that highest density $29.7 \%$ was found in the lowest DBH-class $(2-5 \mathrm{~cm})$ and $16.9 \%, 11.7 \%, 14.5 \%, 15.9 \%, 8.6 \%$ and $2.6 \%$ was found DBH class $2-7$ respectively. The number of individuals of this tree decrease with increasing DBH class but there is slight increase in DBH class 4 and 5. They are represented by the broken up inverted ' $\mathrm{J}$ ' curve structure, this shows good regeneration but discontinuous recruitment in to larger size. One of the possible reasons for the discontinuity could be selective cutting of a particular size of this tree for different purpose. The local people use medium size of these trees for roof cover of their huts and for making fence and the

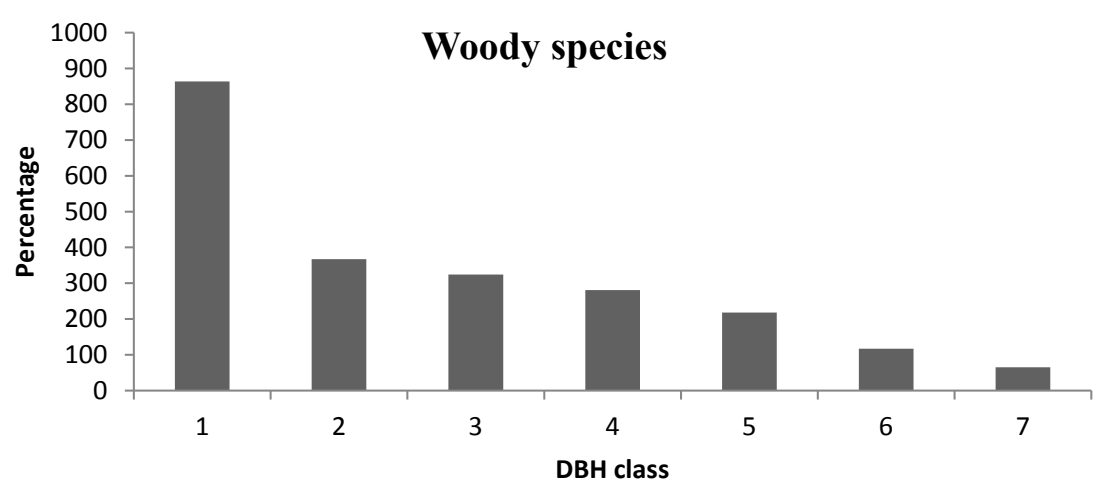

Figure 3. Percentage distribution of woody species in Gole Forest DBH-class (cm).

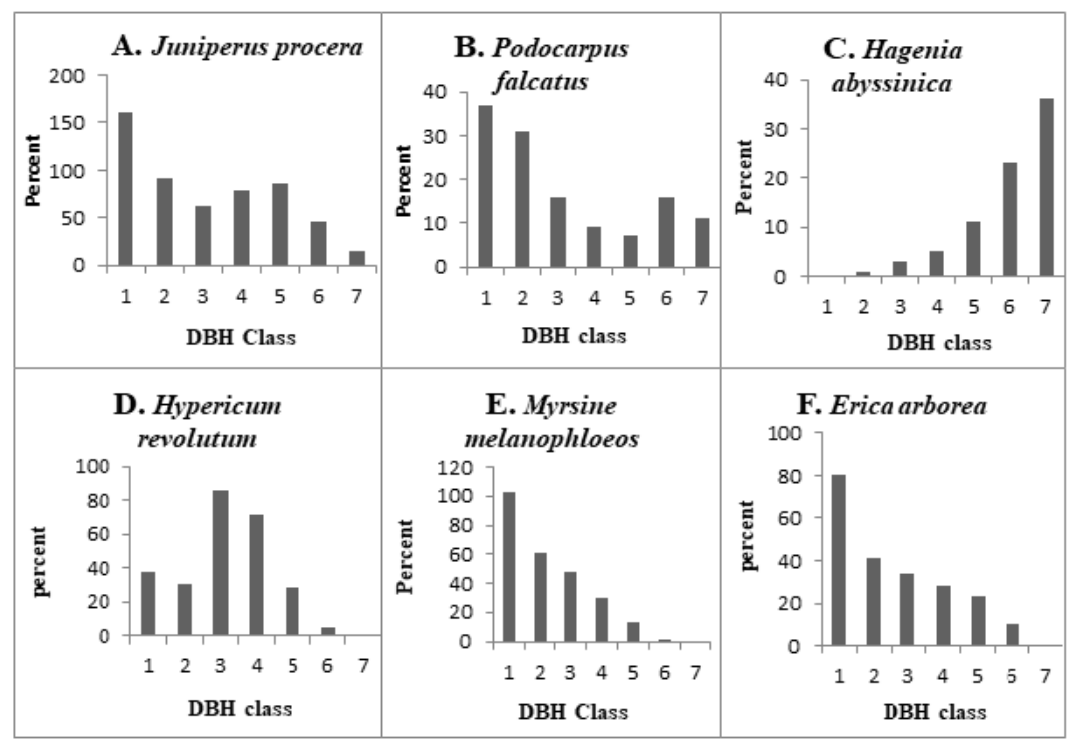

Figure 4. Percentage distribution of individual trees in Gole Forest in DBH-class (cm). 
highest class for timber production as a result the density of these classes was lowered.

The DBH-class of Podocarpus falcatus (Figure 4B) indicates that the highest proportion (29.1\%) of this species was found in lower DBH class (1). The trees having (24.4\%) and (12.6\%) are in the DBH-class 2 and 3 respectively. The remaining proportion $(7.1 \%), 5.5 \%$ and $12.6 \%$ of these trees was observed to a $\mathrm{DBH}$ class between 4, 5 and 6 respectively. The highest DBH class (7) of this tree constitutes $8.7 \%$. They show decreasing pattern of DBH classes up to some limits and then slight increase and decreases. This indicates irregular pattern of distribution, due to selective cutting of a particular size for construction, agricultural, fuel wood and other purpose. It indicates good reproduction but poor recruitment.

There was no Hagenia abyssinica (Figure 4C) in the lower DBH class (1). Small proportion of this tree species was found in the DBH-class 2, 3, 4 and 5, which accounts 1.3\%, 3.8\%, 6.3\% and $13.9 \%$ respectively. The highest DBH-class 6 and 7 comprise $29.1 \%$ and $45.6 \%$ respectively. The number of individual of this tree increases with increasing DBH class, as the majority found above $80 \mathrm{~cm}$. This is due to the fact that male and female individuals of Hagenia abyssinica were found on separate plant, which affects the reproductive capacity of the species, which in turn lowers reproduction. The other probable reason could be Hagenia abyssinica is one of the most useful medicinal plants in the area. The female parts are used as a remedy for tapeworm infestation, which affects the production of viable seeds to germinate and enhance seedling and young population.

The DBH class distribution of Hypericum revolutum (Figure 4D) also indicate considerable proportion was found in the DBH class $14.6 \%$ and in the second class DBH $11.9 \%$. The largest proportion (33.1\%) and (27.7\%) was recorded in the third and fourth DBH class respectively. The individuals belonging to the DBH class was $10.8 \%$. The smallest proportion $1.9 \%$ of this tree was in the sixth DBH-class. There is no Hypericum revolutum in the seventh $\mathrm{DBH}$ class; this is due to the nature of the plants not to grow to higher DBH class.

The DBH class distribution of Myrsine melanophloeos and Erica arborea (Figure 4E and 4F) was shown that high density in the lower DBH class $(40.2 \%$ and $37 \%)$ respectively. The density of Myrsine melanophloeos and Erica arborea decreases with increasing DBH class. They represented by inverted ' $J$ ' curve structure, this pattern shows good reproduction and regeneration potential. On the other hand the low level of mature trees that the forest affected by collection of fuel wood, for household consumption, for sale and construction. There is no Myrsine melanophloeos and Erica arborea in the highest DBH class; this is due to the nature of the plants not to grow to higher DBH class (Figure 4).

\section{Height-class distribution}

Seven height classes 1) 1.5-5 m, 2) 5.01-10 m, 3) 10.01-15 m, 4) $15.01-20 \mathrm{~m}, 5) 20.01-25 \mathrm{~m}, 6) 25.01-30 \mathrm{~m}, 7$ ) $>30.01 \mathrm{~m}$ were established. The number of individuals in each successive height class decreased beginning from the lower height class (1.5-5 $\mathrm{m})$ to the highest height class $(>30.01 \mathrm{~m})$. Most of the woody species in the study area belongs to the lower height class. The highest height class comprises 9.3/ha (1\%) occupied by Juniperus procera (82.6\%) and Podocarpus falcatus (17.4\%). Juniperus procera is the emergent tree and grow above all trees (Figure 5).

The height distribution patterns of Gole Forest was characterized by fewer individuals at matured stage than middle and young age, suggesting that the Forest was dominated by low height individuals, indicating good regeneration but low recruitment.

The separate analysis of Juniperus procera from the lower height class $(1.5-5 \mathrm{~m})$ to the highest height class $(>30.01 \mathrm{~m})$ shows that, $22.7 \%, 15 \%, 6.5 \%, 20.8 \%, 22.5 \%, 8.9 \%$ and $3.5 \%$ respectively. This indicates irregular or Zigzag pattern due to selective cutting for different purpose by the local people, which lower the proportion of medium height class and highest height-classes (Figure 6A).

In Podocarpus falcatus, there is many individuals in the $(37.8 \%)$ and second (31.5\%) height class but less individuals in third $(0.8 \%)$, fourth $(7.9 \%), \quad(4.7 \%)$ and seventh $(3.1 \%)$ height classes and medium number of individuals in the sixth $(14.2 \%)$ height class. This indicates an irregular pattern of distribution. This kind of distribution is observed when there is selective cutting of trees for a particular purpose (Figure 6B).

Hagenia abyssinica shows slightly a bell-shaped distribution pattern (Figure 6E) due to highest density in the third $(20.3 \%)$ and fourth $(21.5 \%)$ height classes, less in the $\quad(7.6 \%)$ and second height class $(15.2 \%)$ and medium height in the $(18.9 \%)$ and sixth (16.5\%) height classes. There is no Hagenia abyssinica in the highest height class. This is due to timber production and the separation of male and female plant reduces the number of lower height class.

In Erica arborea (Figure 6C), Myrsine melanoploeos (Figure $6 \mathrm{D})$ and Hypericum revolutum (Figure 6E and F) respectively, all have high density in the lower height class and gradually

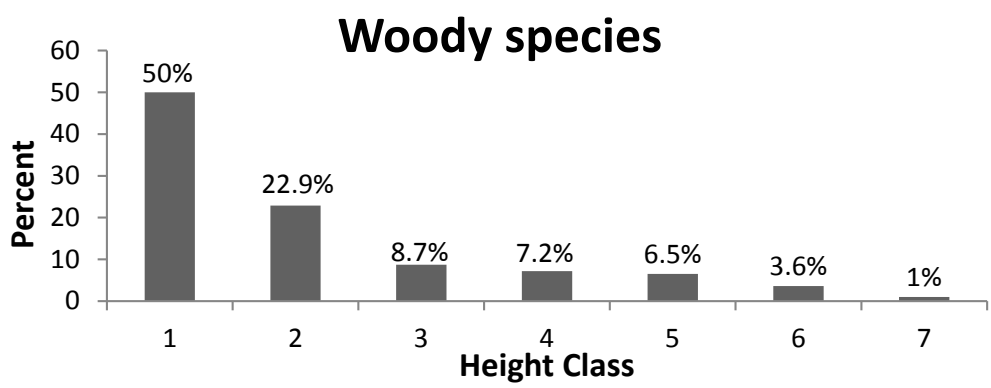

Figure 5. Percentage distribution of woody species in Gole Forest Height-class (m). 
Citation: Hailemariam MB, Temam TD. The vegetation composition, structure and regeneration status of Gole Natural Forest, West Arsi Zone, Oromia Regional State, Ethiopia. J Agric Sci Bot. 2018;2(2):10-21.

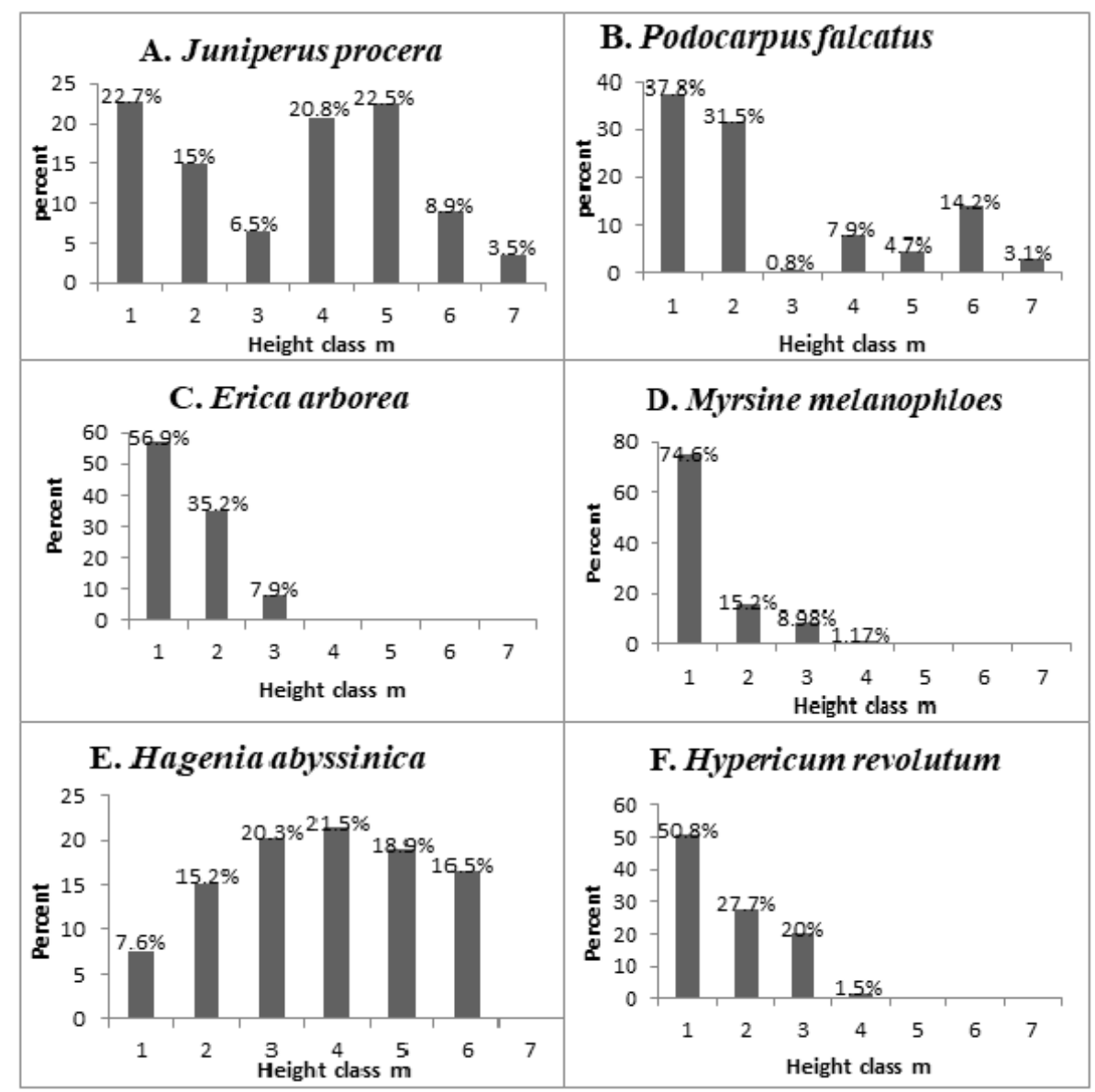

Figure 6. Percentage distribution of individual tree species in Gole forest in height class $(m)$.

decreases with increasing height class. They show an inverted "J" shape pattern of height distribution. This is due to less human interference as they are found at the highest altitude and the nature of the tree not to grow in to the highest height class (Figure 6).

\section{Vertical structure}

The vertical structure of tree species was analyzed in to three vertical layers. These are upper storey (top height $>30 \mathrm{~m}$ ), middle storey (height between 15-30 m) and lower storey (height $<15 \mathrm{~m}$ ) [28].

The lower storey contributed to $77.3 \%$ of all tree species. The most dominant trees in the lower story was Hypericum revolutum (18.3\%), Myrsine melanophloeos (18\%), Juniperus procera (17\%), Erica arborea (15.4\%), Mytenus arbutifolia (6.9\%), Podocarpus falcatus (6.4\%) and the remaining accounts less than $3 \%$ each. The middle storey $(15-30 \mathrm{~m})$, contributed about $21.4 \%$ of the tree species. This layer was dominated by Juniperus procera (76.8\%), Hagenia abyssinica (11.6\%), Prunus africana (1.3\%), Podocarpus falcatus (8.8\%), Ficus sur $(1.5 \%)$ and the remaining contributed less than $1 \%$ each. The upper storey contributes only $1.3 \%$ of the total individual's trees in the forest. The two dominant emergent tree species in this layer were Juniperus procera $(82.6 \%)$ and Podocarpus falcatus $(17.4 \%)$. Only two tree species $(9 \%)$ were common to all storeys. In general, the percent of tree densities in lower, middle and upper storey was found to be 564.1 ha, 156.5/ha and 9.3/ha respectively (Table 3 ).
Table 3. The percentage distribution of trees in lower, middle and upper strata.

\begin{tabular}{|c|c|c|c|}
\hline Storey & Density/ha & No of species & $\%$ \\
\hline Lower & 564.1 & 22 & 77.3 \\
\hline Middle & 156.5 & 12 & 21.4 \\
\hline Upper & 9.3 & 2 & 1.3 \\
\hline
\end{tabular}

\section{Basal area}

The total basal area of tree species in Gole Forest was calculated from DBH data and it was found to be $49.2 \mathrm{~m}^{2} /$ ha. About $90.8 \%$ of the total basal area is contributed by Juniperus procera $33.3 \%$, Hagenia abyssinica 17.9\%, Hypericum revolutum $11.6 \%$, Podocarpus falcatus $8.9 \%$, Erica arborea $7.9 \%$, Mytenus arbutifolia 5.9\% and Myrsine melanophloeos 5.3\%. Species with the highest basal area do not necessarily have the highest density, indicating size difference between the species [35]. Myrsine melanophloeos have highest density but low in basal area and Hagenia abyssinica have low density but high in basal area. Therefore, the trees belonging to higher DBH classes contribute higher to the total basal area than trees with low DBH class. Basal area provides a better measure of the relative importance of the species than simple stem count [36]. Thus, Species with the largest basal area can be considered as the most important species in the forest (Table 4).

\section{Frequency}

Frequency is the indication of homogeneity and heterogeneity of given vegetation in which the higher number of species in 
Table 4. The Basal area of trees $\left(\mathrm{m}^{2} / \mathrm{ha}\right)$ and their percentage contributions.

\begin{tabular}{|c|c|c|c|}
\hline No & Species & $\begin{array}{c}\text { Basal Area } \\
\mathbf{m}^{\mathbf{2}} \mathbf{h a}\end{array}$ & $\%$ \\
\hline 1 & Allophylus abyssinicus & 0.02 & 0.04 \\
\hline 2 & Buddleja polystachya & 0.01 & 0.02 \\
\hline 3 & Dombeya torrida & 0.9 & 1.8 \\
\hline 4 & Ekebergia capensis & 0.1 & 0.2 \\
\hline 5 & Erica arborea & 3.9 & 7.9 \\
\hline 6 & Ficus sur & 0.4 & 0.8 \\
\hline 7 & Galiniera saxifraga & 0.6 & 1.2 \\
\hline 8 & Hagenia abyssinica & 8.8 & 17.9 \\
\hline 9 & Hypericum revolutum & 5.7 & 11.6 \\
\hline 10 & Ilex mitis & 0.1 & 0.2 \\
\hline 11 & Juniperus procera & 16.4 & 33.3 \\
\hline 12 & Maesa lanceolata & 0.1 & 0.2 \\
\hline 13 & Myrsine melanophloeos & 2.6 & 5.3 \\
\hline 14 & Mytenus arbutifolia & 2.9 & 5.9 \\
\hline 15 & Nuxia congista & 0.7 & 1.4 \\
\hline 16 & Olea europea sub.sp.cuspidata & 0.6 & 1.2 \\
\hline 17 & Olinia rachetiana & 0.1 & 0.2 \\
\hline 18 & Pittosporum viridiflorum & 0.1 & 0.2 \\
\hline 19 & Podocarpus falcatus & 4.4 & 8.9 \\
\hline 20 & Prunus africana & 0.3 & 0.6 \\
\hline 21 & Rhamnus staddo & 0.2 & 0.4 \\
\hline 22 & Schefflera volkensii & 0.3 & 0.6 \\
\hline & Total & 49.2 & 100 \\
\hline & & & \\
\hline & & & \\
\hline
\end{tabular}

higher frequency classes and low number of species in lower frequency classes show similar species composition while large number of species in lower frequency classes and small number of species in higher frequency classes indicates higher heterogeneity (Table 5) [37].

The above table shows the most frequent herb, climber, shrub and tree species of Gole forest. Gole forest is heterogeneous in its diversity.

\section{Importance value index (IVI)}

The importance value index of tree species in Gole Forest is given in Table 6. The highest IVI of Juniperus procera was as a result of high relative frequency, relative density and relative dominance. In Hagenia abyssinica the highest basal area made the species to have large value of relative dominance and hence got the highest Importance value index (Table 6).

The most dominant and ecologically important tree species of Gole Forest were Juniperus procera, Myrsine melanophloeos, Hypericum revolutum, Hagenia abyssinica, Podocarpus falcatus and Erica arborea. The leading dominant and ecologically most species might also be the most successful species [36]. Priority for conservation should be given based on their Importance value index values. i.e. the priority for species with least Importance value index because they are at risk of local extinction and the last priority of conservation for species with highest Importance value index.

\section{Vegetation community classification}

The plant community types were recognized using Agglomerative hierarchical cluster analysis. Communities were on the basis of quadrats grouping by similarity [38,39].

Agglomerative hierarchical cluster analysis revealed that there are main plant communities in the study area, designated as community 1, 2, 3, 4, and 5 as shown in (Figure 7).

Community1: includes plot: 1, 2, 3 and 4

Community2: includes plot: 5,6,7,8,9,10,12,13,14,15,16,17,18 $, 19,22$ and 23

Community 3: includes plot: $11,20,21,24,25,26,27,28,29,30$ and 31

Table 5. List of the most frequent plant species in Gole Forest.

\begin{tabular}{|c|c|c|c|c|}
\hline Species & Habit & $\begin{array}{c}\text { No of plot } \\
\text { present }\end{array}$ & $\begin{array}{c}\text { Total plot } \\
\text { sampled }\end{array}$ & $\%$ \\
\hline Erica arborea & Tree & 18 & 62 & 29 \\
\hline Hagenia abyssinica & $"$ & 26 & 62 & 41.9 \\
\hline Hypericum revolutum & $"$ & 28 & 62 & 45.2 \\
\hline Juniperus procera & $"$ & 55 & 62 & 88.7 \\
\hline Myrsine melanophloeos & $"$ & 47 & 62 & 75.8 \\
\hline Mytenus arbutifolia & $"$ & 24 & 62 & 38.7 \\
\hline Podocarpus falcatus & $"$ & 24 & 62 & 38.7 \\
\hline Rubus apetalus & Shrub & 49 & 62 & 79 \\
\hline Discopodium penninervum & $"$ & 28 & 62 & 45 \\
\hline Rosa abyssinica & $"$ & 26 & 62 & 42 \\
\hline Mikaniopsis clematoides & Climber & 40 & 62 & 65 \\
\hline Aspargus africanus & $"$ & 35 & 62 & 56.5 \\
\hline Caucanthus auriculatus & $"$ & 24 & 62 & 39 \\
\hline Helichrysum formosissmum & Herb & 42 & 62 & 68 \\
\hline Kalanchoe petitiana & $"$ & 31 & 62 & 50 \\
\hline Myosotis abyssinica & $"$ & 31 & 62 & 50 \\
\hline Carduus nyassanus & $"$ & 30 & 62 & 48 \\
\hline Haplocarpha schimperi & $"$ & 29 & 62 & 47 \\
\hline Kniphofia foliosa & $"$ & 27 & 62 & 44 \\
\hline Cyanoglossum amplifolium & $"$ & 27 & 62 & 44 \\
\hline & & & & \\
\hline & & 42 & 62 & 62 \\
\hline
\end{tabular}

Table 6. Importance value index of trees species in Gole Forest.

\begin{tabular}{|c|c|c|c|c|c|}
\hline No & Species & $\begin{array}{l}\text { Relative } \\
\text { Frequency }\end{array}$ & $\begin{array}{l}\text { Relative } \\
\text { density }\end{array}$ & $\begin{array}{c}\text { Relative } \\
\text { dominance }\end{array}$ & $\begin{array}{l}\text { Importance } \\
\text { value index }\end{array}$ \\
\hline 1 & Allophylus abyssinicus & 0.9 & 0.2 & 0.04 & 1.14 \\
\hline 2 & Buddleja polystachya & 0.6 & 0.2 & 0.02 & 0.82 \\
\hline 3 & Dombeya torrida & 2.5 & 1.8 & 1.8 & 6.1 \\
\hline 4 & Ekebergia capensis & 1.9 & 0.6 & 0.2 & 2.7 \\
\hline 5 & Erica arborea & 5.5 & 9.6 & 7.9 & 23 \\
\hline 6 & Ficus sur & 0.3 & 0.5 & 0.8 & 1.6 \\
\hline 7 & Galiniera saxifraga & 4.6 & 1.3 & 1.2 & 7.1 \\
\hline 8 & Hagenia abyssinica & 7.9 & 3.3 & 17.9 & 29.1 \\
\hline 9 & Hypericum revolutum & 8.6 & 10.9 & 11.6 & 31.1 \\
\hline 10 & Ilex mitis & 0.3 & 0.08 & 0.2 & 0.58 \\
\hline 11 & Juniperus procera & 16.9 & 28 & 33.3 & 78.2 \\
\hline 12 & Maesa lanceolata & 0.6 & 0.5 & 0.2 & 1.3 \\
\hline 13 & Myrsine melanophloeos & 14.5 & 21.5 & 5.3 & 41.3 \\
\hline 14 & Mytenus arbutifolia & 7.4 & 5.4 & 5.9 & 18.7 \\
\hline 15 & Nuxia congista & 4.9 & 1.7 & 1.4 & 8 \\
\hline 16 & $\begin{array}{l}\text { Olea europea sub. } \\
\text { sp.cuspidata }\end{array}$ & 4.6 & 2.5 & 1.2 & 8.3 \\
\hline 17 & Olinia rachetiana & 1.9 & 0.5 & 0.2 & 2.6 \\
\hline 18 & Pittosporum viridiflorum & 1.9 & 0.4 & 0.2 & 2.5 \\
\hline 19 & Podocarpus falcatus & 7.4 & 9.4 & 8.9 & 25.7 \\
\hline 20 & Prunus africana & 0.9 & 0.3 & 0.6 & 1.8 \\
\hline 21 & Rhamnus staddo & 1.2 & 0.6 & 0.4 & 2.2 \\
\hline \multirow[t]{2}{*}{22} & Schefflera volkensii & 4.6 & 0.9 & 0.6 & 6.1 \\
\hline & Total & & & & 299.94 \\
\hline
\end{tabular}


Citation: Hailemariam MB, Temam TD. The vegetation composition, structure and regeneration status of Gole Natural Forest, West Arsi Zone, Oromia Regional State, Ethiopia. J Agric Sci Bot. 2018;2(2):10-21.

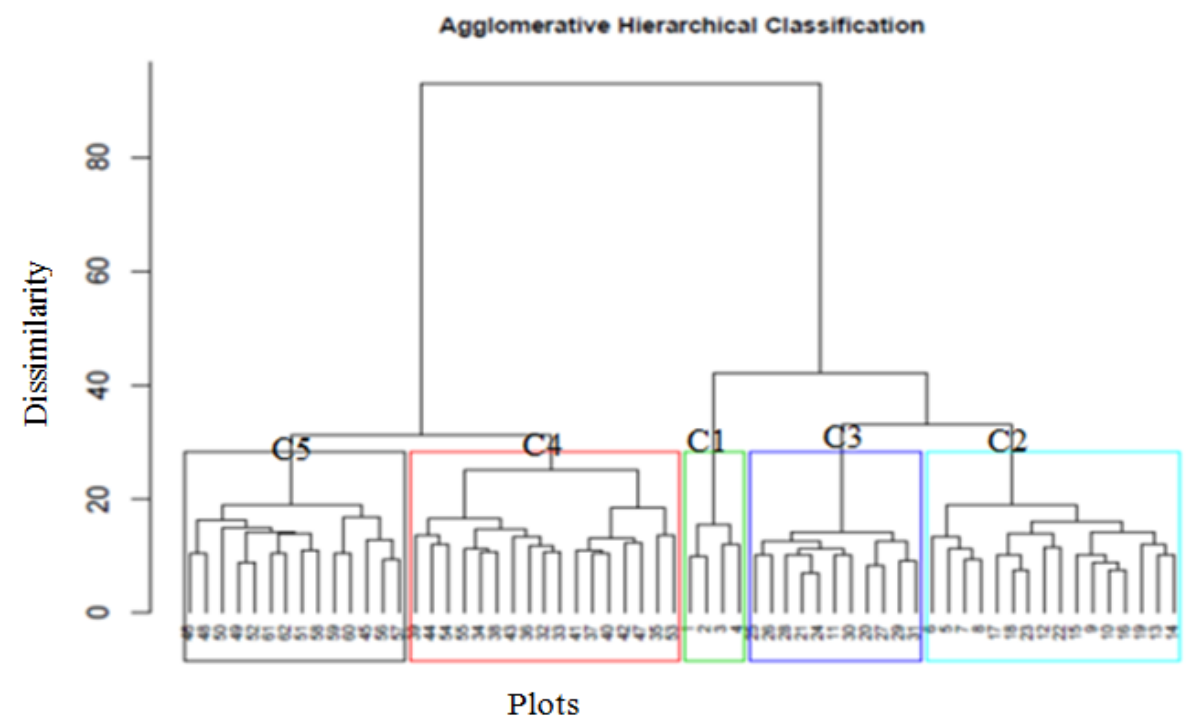

Figure 7. Denrogram showing five plant community types in Gole Forest.

Community 4: includes plot: $32,33,34,35,36,37,38,39,40,41,42$ ,43,44,47,53,54 and 55

Community 5: includes plot: 45,46,48,49,50,51,52,56,57,58,59 $, 60,61$ and 62

The species with highest indicator values are bolded and used for naming the communities. The indicator values are determined by combining the relative abundance and relative frequencies of each species. The indicator values of the species are considered as if the respective probability values are less than 0.05 (Table 7) [40].

The plant communities which were in the study area are described as follows:

Community 1: Erica arborea-Conyza spinosa community type: This community type was found at the highest altitude ranging between 3388 and $3480 \mathrm{~m}$ a.s.1. This community resulted from 4 plots and 27 species. The tree layer was highly dominated by Erica arborea and the shrub layer by Conyza spinosa. The dominant herbaceous species of this community was Thymus schimperi, Isolepis setacea, Crepis reupeli, Helichrysum splendidum, Crinium abyssinicum, Gnaphalium rubriflorum and Trifolium quartinianum and the grass species of this community was Cyprus fischirianus and Festuca abyssinica.

Community 2: Hypericum revolutum community type: There were 16 plots and 50 species included in this community and found at an altitude between 3173 and $3350 \mathrm{~m}$ a.s.l. The tree layer was dominated by Hypericum revolutu. The herbaceous species of this community type includes Bidens pachyloma, Carduuus nyassanus, Cyanatis berbata, Stellaria senni and Periploca linearifolia.

Community 3: Hagenia abyssinica-Myrsine melanophloeosJuniperus procera community: This community type was found at an altitudinal ranging between 3050 and $3275 \mathrm{~m}$ a.s.1. The community consists of 11 plots and 40 species. The tree layer of this community was dominated by Hagenia abysinica, Myrsine melanophloeos, Juniperus procera and the dominant shrub of this community was Discopodium penninervum and the herbaceous species of this community was Kalanchoeo petitiana and Kniphofia foliosa.

Community 4: Nuxia congista-Myrsine africana-Osyris quadripartita community type: This community type was composed of 17 plots and 78 species and located at an altitude between 2758 and $3040 \mathrm{~m}$ a.s.1. The tree layer was dominated by Nuxia congista, Dombeya torrida, Olea europea subsp. cuspidata and the dominated shrub of this community was Myrsine africana, Osyris quadripartita and Inula conifertiflora. The dominated herbacious species was Minulopsis solmisii and Dryopteris anthamantica.

Community 5: Podocarpus falcatus-Mytenus arbutifoliaDovyalis abyssinica community type: This community type was found at the lowest altitude ranging between 2728 and 2863 $\mathrm{m}$ a. s. 1 . The community consists of 14 plots and 75 species. The dominant tree species of this community type was Podocarpus falcaatus, Mytenus arbutifolia and Prunus africana, and the shrub layer of this community was dominated by Dovyalis abysinica, Rosa abyssinica and Mytenus addat. The herbaceous species dominating this community was Myosotis abyssinica and Carduus camaecephalus, and the dominant climber of this community was Mikaniopsis clematoids.

\section{Community Similarity Analysis}

Sorenson's of similarity was computed to see whether communities and species composition is discontinuous or continuous (Table 8).

Sorenson's of similarity on the species composition between communities indicates that, community one shares more species with communities two $(26 \%)$ and three $(22 \%)$ but relatively low with community four (18\%) and (11\%). Community two shares more species with community three (41\%) and four (36\%) and relatively less species with community (26\%). Community three shares more species with community four $(44 \%)$ than with community $\quad(40 \%)$. Community four share more species with community $\quad(59 \%)$ than any other communities. 
Table 7. List of Species with significant indicator values (in percentage) in each community and the montecarlo test of significance $\left(P^{*}\right)$.

\begin{tabular}{|c|c|c|c|}
\hline Species & Community & $\begin{array}{c}\text { Indicator } \\
\text { value }\end{array}$ & $P^{*}$ Value \\
\hline Thymus schimperi & 1 & 89.47 & 0.001 \\
\hline Isolepis setacea & 1 & 75 & 0.001 \\
\hline Erica arborea & 1 & 65.91 & 0.001 \\
\hline Cyprus fischerianus & 1 & 65.25 & 0.001 \\
\hline Crepis reupeli & 1 & 55.44 & 0.004 \\
\hline Arsaema schimperiana & 1 & 50 & 0.007 \\
\hline Festuca abyssinica & 1 & 47.06 & 0.005 \\
\hline Helichrysum splendidum & 1 & 47.06 & 0.004 \\
\hline Conyza spinosa & 1 & 46.85 & 0.002 \\
\hline Helichrysum foetidium & 1 & 46.67 & 0.002 \\
\hline Crinium abyssinicum & 1 & 42.58 & 0.004 \\
\hline Gnaphalium rubriflorum & 1 & 41.8 & 0.008 \\
\hline Trifolium qurtinianum & 1 & 29.34 & 0.032 \\
\hline Bides pachyloma & 2 & 56.62 & 0.002 \\
\hline Hypericum revolutum & 2 & 46.36 & 0.003 \\
\hline Carduus nyasanus & 2 & 36.84 & 0.022 \\
\hline Cyanatis berbata & 2 & 26.77 & 0.045 \\
\hline Stellaria senii & 2 & 25.62 & 0.041 \\
\hline Periploca linearifolia & 2 & 25 & 0.023 \\
\hline Discopodium penninervum & 3 & 46.48 & 0.001 \\
\hline Hagenia abyssnica & 3 & 43.59 & 0.009 \\
\hline Myrsine melanophloeos & 3 & 34.49 & 0.002 \\
\hline Kalanchoe petitiana & 3 & 34.23 & 0.036 \\
\hline Kniphofia foliosa & 3 & 31.33 & 0.035 \\
\hline Juniperus procera & 3 & 31.16 & 0.001 \\
\hline Myrsine africana & 4 & 72.37 & 0.001 \\
\hline Osyris qudripartita & 4 & 40.64 & 0.007 \\
\hline Inula conifertiflora & 4 & 39.68 & 0.008 \\
\hline Nuxia congista & 4 & 38.96 & 0.007 \\
\hline Minulopsis solmisi & 4 & 36.31 & 0.014 \\
\hline Dombeya torrida & 4 & 34.83 & 0.013 \\
\hline Olea europea sub sp cuspidata & 4 & 30.35 & 0.038 \\
\hline Dryopteris anthemantica & 4 & 26.89 & 0.028 \\
\hline Podocarpus falcatus & 5 & 76.76 & 0.001 \\
\hline Mytenus arbutifolia & 5 & 59.95 & 0.001 \\
\hline Dovyalis abyssinica & 5 & 53.97 & 0.002 \\
\hline Solanum indicum & 5 & 46.76 & 0.009 \\
\hline Rosa abyssinica & 5 & 44.46 & 0.009 \\
\hline Mikaniopsis clematoids & 5 & 38.68 & 0.003 \\
\hline Myosotis abyssinica & 5 & 34.31 & 0.032 \\
\hline Mytenus addat & 5 & 24.85 & 0.04 \\
\hline Carduus camaecephalus & 5 & 21.43 & 0.022 \\
\hline Prunus africana & 5 & 21.43 & 0.023 \\
\hline
\end{tabular}

Gradual change in species composition and diversity was observed in the study area. The overall similarity ranges from $11-59 \%$ among all the communities. The highest similarity was observed between community four and $(59 \%)$, three and four $(44 \%)$ and two and three $(41 \%)$. This is due to existence of most quadrates adjacent to each other and similarity in altitudes that shows the availability of nutrient needed by those species and the adaptation of plants to that particular environment. The lowest similarity was observed between community one and $\quad(11 \%)$, one and four $(18 \%)$ and one and three (20\%), this shows that community having nearly similar altitude have more species in common than communities occupying different altitude. If two sites have similar vegetation they have similar environment and if two sites have different vegetation they have different environment [41].

\section{Species richness comparison}

The rarefaction curves shows that, species richness was greater in community four (50), followed by community (44), while species richness in community two (34) was intermediate but in community three (28) and one (27) is less. The species evenness also greater in community four, as the rarefaction curve is steeper followed by community Less even distribution of species was observed in community one, three and two as the rarefaction curve is relatively less steep (Figure 8).

The reason why community four has the highest species richness is that there are fewer disturbances in this community and mainly cover with shrubs which is less valuable woody species for commercial purpose and also resistant to wild animal and livestock grazing, like Osyris quadripartita and Myrsine africana. In community at low elevation, even if disturbance level is greater, species richness is high next to community four; this is because of moderate conditions which permit rapid resource acquisition which is favorable for most plant growth. In community three and two the decrease in species richness than community four and is due to disturbance and increase in altitude. The decrease in species richness of community one which is found at the highest altitude could be due to eco-physiological constraints, such as reduced growing season, low temperature and low productivity and other factors such as soil fertility and soil acidity. The soil $\mathrm{pH}$ decreases with increasing altitude and as a result the soil acidity increases with rising altitude and this could affect the chemical reaction between plant roots and nutrients and microbial activity. These could be the possible reasons for declining of species richness and diversity with increasing altitude [35].

\section{Regeneration status of gole forest}

The regeneration status of a forest was summarized based on the total count of seedlings and saplings of each species across all plots. From the study area a total of 710 seedlings (286.3/ha) of 15 tree species and 471 saplings (189.9/ha) from 17 tree species were recorded.

These tree species contribute $21.9 \%$ of the total composition of the study area. Fifteen species contributes $28 \%$ and seventeen species contributes $18.7 \%$ of the total seedling and sapling count respectively. Schefflera volkensii, Pittosporum abyssinicum, Olinia rachetiana, Ilex mitis, Prunus africana, Allophylus abyssinicus and Ficus sur do not have seedlings. The other Hagenia abyssinica, Pittosporum abyssinicum, Galiniera saxifraga, Maesa lanceolata and Ilex mitis do not

Table 8. Sorenson's coefficient of Similarity between the Plant Communities of Gole Forest.

\begin{tabular}{|c|c|c|c|c|c|}
\hline Community & $\mathbf{1}$ & $\mathbf{2}$ & $\mathbf{3}$ & $\mathbf{4}$ & $\mathbf{5}$ \\
\hline 1 & 1 & - & & & \\
\hline 2 & 0.26 & 1 & - & & \\
\hline 3 & 0.2 & 0.41 & 1 & - & \\
\hline 4 & 0.18 & 0.36 & 0.44 & 1 & - \\
\hline 5 & 0.11 & 0.26 & 0.4 & 0.59 & 1 \\
\hline
\end{tabular}


Citation: Hailemariam MB, Temam TD. The vegetation composition, structure and regeneration status of Gole Natural Forest, West Arsi Zone, Oromia Regional State, Ethiopia. J Agric Sci Bot. 2018;2(2):10-21.

have saplings. The two species Pittosporum abyssinicum and Ilex mitis do not have both seedling and saplings. All the rest have both seedling and sapling. Accordingly, tree species with the largest (more than 5\%) contribution to the seedling counts were Myrsine melanophloeos (40.3\%), Juniperus procera (23.7\%), Podocarpus falcatus (15.5\%), Mytenus arbutifolia $(5.4 \%)$, and Olea europea sub.sp. cuspidata (5.2\%), show the highest seedling counts of the tree species.

The ratio of parent plant to seedling was 1:3.5 and that of parent to sapling was 1:5. The tree species that lacks seedling and sapling or either of the two should be given priority for conservation. Thus, Pittosporum abyssinicum, Ilex mitis, Schefflera volkensii, Olinia rachetiana, Prunus africana, Allophylus abyssinicus and Ficus sur need priority conservation (Figure 9).

The pattern of distribution shows maximum number of matured plant than saplings and seedlings. These might be seeds in seed banks are eaten before they germinate, or death of seedlings with unsuitable resource or with herbivores and pathogens. And also the environmental conditions of soil moisture, temperature and light conditions alter the germination and/or survival of seedlings.

\section{Phyto-geographical comparison}

The direct comparison of the species diversity of one forest with other forests is not feasible due to variations in size, survey methods used, and objective of the study among forests [42]. However, the overall species richness of the forest can give more or less a general impression of their diversity and phytogeographical similarity. In this regard Gole forest was compared with other forests in the country to see the distribution pattern of plant species in the study area and to know the relative similarity in its plant species composition (Table 9).

Sorenson's index of similarity indicates that, Denkoro and Sanka meda forests have highest similarity (39\%) with Gole forest than the other mentioned forests followed by Gedo and Biteyu forests with similarity of $37 \%$ and $35 \%$ respectively. Bibita forest shows the lowest similarity $17 \%$ with Gole forest.

The probable reason for the highest similarity between Denkoro forests and Gole forest is that both the range of altitude and both are dry evergreen afromontane forest. Sanka meda forest and Gole forest also show highest similarity, this is because both are dry evergreen afromontane forest. Gedo and Biteyu forest also show good similarity with Gole forest due to the range of

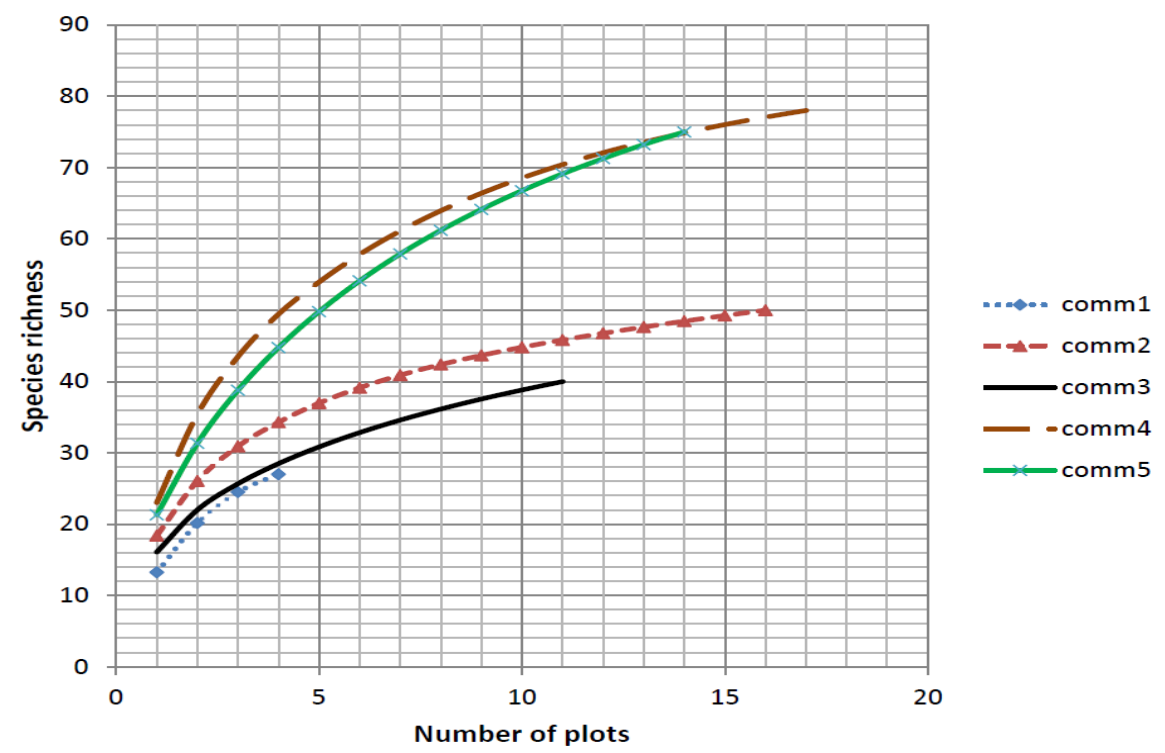

Figure 8: Comparisons of species richness between plant communities using rarefaction measurements.

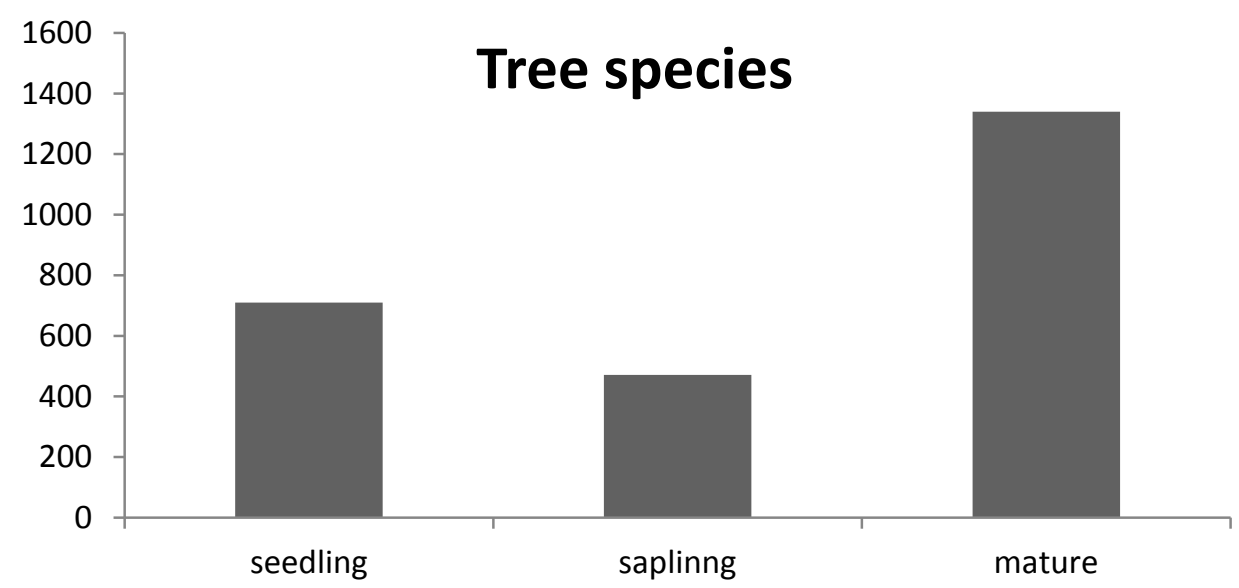

Figure 9: The regeneration pattern of Gole Forest represented by tree species. 
Table 9. Phytogeographical comparison between Gole forest and other five Forests.

\begin{tabular}{|c|c|c|c|c|c|c|c|}
\hline Forest & Altitude range & $\begin{array}{c}\text { No of } \\
\text { species }\end{array}$ & a & b & c & Ss & Source \\
\hline Gole forest & $2728-3480$ m a.s.I & 114 & & & & & \\
\hline Bibita forest & $900-2200$ m a.s.I & 196 & 26 & 88 & 170 & 0.17 & {$[35]$} \\
\hline Gedo forest & $1300-3060$ m a.s.I & 235 & 65 & 49 & 170 & 0.37 & {$[36]$} \\
\hline Biteyu forest & $2590-2890$ m a. s.I & 177 & 51 & 63 & 126 & 0.35 & {$[43]$} \\
\hline Denkoro forest & $1500-3500$ m.a.s.I & 174 & 57 & 57 & 119 & 0.39 & {$[44]$} \\
\hline Sanka meda forest & $2400-2748$ m a.s.I & 140 & 49 & 65 & 87 & 0.39 & {$[45]$} \\
\hline
\end{tabular}

altitude and vegetation type both are dry evergreen afromontane forest. Bibita forest which is moist evergreen afromontane forests is much less similar with Gole forest due to difference in altitude and difference in their vegetation type.

\section{Conclusion and Recommendation}

From the study area, 114 species of plants belonging to 94 genera and 57 families were Asteraceae had the highest number of species. Out of 114 species 17 were endemic to Ethiopia. The density of woody species in Gole Forest decreases with increasing DBH and Height classes. Few species occur in all DBH and Height classes showing variation in population size. Three layers were from the vertical

(the upper, the middle and the lower storey). IVI $\operatorname{six} \square$ dominant tree species which is ecologically important species of the forest and they contributed $84.9 \%$ of the total basal area. Five plant community types were There are variations in species composition and diversity among the communities. The species richness was high in communities 4 and 5 but relatively less in community 2,3 and 1 . The regeneration status of tree species showed that there are two major types of tree species, species able to regenerate and others with to regenerate.

Gole natural forest was one of the remnant forests with in Adaba-Dodola forest priority area in Ethiopia. To conserve this forest appropriate management strategy is vital. This study was done only on one site of Adaba-Dodola forest priority area. The study of the whole Adaba-Dodola Forest is recommended to know the current status of the vegetation of the area [43-45].

Further studies are needed to the gap of this work such as analysis of soil sampling.

Seventeen plant species were found to be endemic to Gole natural forest (Ethiopia). This shows that the area has a potential for the presence of more endemic species. Thus, further study on the whole Adaba-Dodola Forest is recommended.

The vegetation of Gole Forest was disturbed through grazing and browsing by domestic livestock and other human uses (selective cutting), these further affects the regeneration processes of the forest. Therefore, this forest needs to be protected and utilizeed in a sustainable way.

Even though it is not included in this study, people in the area uses the vegetation in the forest for different purpose like for medicine (i.e. Hagenia abyssinica for intestinal worm, Vernonia amygdalina for fever of domestic animals and others). Thus detailed ethinobotanical study on Gole Forest is highly recommended.
Finally, Gole forest is not well known, this may be because of its remoteness and lack of infrastructure. So the concerned bodies should give attention to solve infrastructure problems and researchers should devote more time to investigate this poorly known area.

\section{References}

1. Gairola S, Rawal RS, Todaria NP. Forest vegetation patterns along an altitudinal gradient in sub-alpine zone of west Himalaya, India. Afr J Plant Sci. 2008;2(6):42-8.

2. FAO. State of the World's Forests. Food and Agriculture Organization of the United Nations, Rome. 2007.

3. IBC. Convention on Biological Diversity (CBD) Ethiopia's $4^{\text {th }}$ Country Report. Addis Ababa, Ethiopia. 2009.

4. FAO. Global forest resource assessment, Food and Agriculture Organization report, Rome, Italy. 2010.

5. Suzana S, Mataya B, Senelwa K, et al. Non Wood Forest Products and Services for Socio-Economic Development. African Forest Forum. 2011.

6. Amente G. Integrated and participatory forest management

$\square$ in the Bale Mountains of Ethiopia. International Symposium towards Sustainable livelihoods and ecosystems in mountainous regions, Chiang Mai, Thailand. 2006.

7. Friis I, Demissew S, Van Bruegel P. Atlas of the Potential Vegetation of Ethiopia. The Royal Danish Academy of Science and letters, Biologiske Skrifter. 2010;58.

8. Mengistu A. Forage Production in Ethiopia: A case study with implications for livestock production. Ethiopian Society of Animal Production (ESAP), Addis Ababa, Ethiopia. 2002.

9. EFAP. Ethiopian Forestry Action Program. Final Report, Ministry of Natural Resources Development and Environmental Protection, Addis Ababa, Ethiopia. 1994.

10. EPA. National Conservation Strategy of Ethiopia: executive summary. Environmental Protection Authority, Addis Ababa, Ethiopia. 1997.

11. Schmitt MD, Demissew S, Friis Ib, et al. Floristic diversity in fragmented Afromontane rainforests: Altitudinal variation and conservation importance. Appl Veg Sci. 2010;13:291-304.

12. Beche D. Floristic Composition, Diversity and Structure of Woody Plant Species in Menagesha Suba State Forest, Central Ethiopia, M.Sc. thesis, AAU. 2011.

13. Amente G. Rehabilitation and sustainable use of degraded community forests in the Bale Mountains of Ethiopia. Albert-Ludwigs-University, Freiburg im Breisgau, Germany. 2005.

14. Amente G, Huss J, Tennigkeit T. Forest regeneration without planting: the case of community managed forests in the Bale Mountains of Ethiopia. J Dry Lands. 2006;1(1):26-34.

15. Van Breugel P, Kindt R, Lillesø JP. Potential Natural Vegetation of Eastern Africa (Ethiopia, Kenya, Malawi, Rwanda, Tanzania, Uganda and Zambia). Volume 6: An 
Citation: Hailemariam MB, Temam TD. The vegetation composition, structure and regeneration status of Gole Natural Forest, West Arsi Zone, Oromia Regional State, Ethiopia. J Agric Sci Bot. 2018;2(2):10-21.

Overview of The Methods and Material Used to Develop The Map. Forest \& Landscape Working Paper 68. 2011.

16. Ejero O. Community perception of on farm trees and adjacent natural forest status under participatory management: dodola district, ethiopia. M.Sc. thesis, AAU. 2009.

17. Central Statistical Authority (CSA). The 2007 population and housing census of Ethiopia result for Oromia Region. Addis Ababa. 2007.

18. Singhal RM. Soil and Vegetation Studies in Forests. ICFRE Publications, Debra Dun. 1996:62-5.

19. Van der Maabel E. Tranformation of cover/abundance values in Phytosociology and its effects on community similarity. Vegetatio. 1979;39:47-114.

20. Van der Maarel E. Vegetation ecology -an overview. Blackwell Publishing Company. 2005.

21. Hedberg I, Edwards S. (Eds.) Flora of Ethiopia. Vol 3. Pittosporaceae to Araliaceae. Addis Ababa University and Uppsala University. 1989.

22. Edwards S, Tadesse M, Hedberg I. (Eds.) Flora of Ethiopia and Eritrea. Vol. 2, Part 2. Canellaceae to Euphorbiaceae. Addis Ababa University and Uppsala University. 1995.

23. Edwards S, Demissew S, Hedberg I. (Eds). Flora of Ethiopia. Vol. 6. Hydrocharitaceae to Arecaceae. Addis Ababa University and Uppsala University. 1997.

24. Edwards S, Tadesse M, Demissew S, et al. (Eds.) Flora of Ethiopia and Eritrea. Vol. 2, Part 1. Magnoliaceae to Flacourtiaceae. Addis Ababa University and Uppsala University. 2000.

25. Hedberg I, Edwards S, Nemomissa S. Flora of Ethiopia and Eritrea. Vol. 4, Part 1. Apiaceae to Dipsaceae. Addis Ababa University and Uppsala University. 2003.

26. Hedberg I, Friis I, Edwards S. Flora of Ethiopia and Eritrea Vol. 4, Part 2. Asteraceae (Compositae). Addis Ababa University and Uppsala University. 2004.

27. Hedberg I, Kelbessa E, Edwards S, et al. Flora of Ethiopia and Eritrea Vol. 5. Gentianaceae to Cyclocheilaceae. Addis Ababa University and Uppsala University. 2006.

28. Abdena F. Floristic composition and structure of vegetation of Chato Natural Forest in Horo Guduru Wollega Zone, Oromia National Regional State, west Ethiopia. M.Sc. thesis AAU. 2010.

29. Tesfaye G, Teketay D, Fetene M. Regeneration of 14 tree species in Harenna forest, Southeast Ethiopia. Flora. 2002;197:461-74.

30. R Development Core Team. R version 2.10.1. The $\mathrm{R}$ Foundation for Statistical Computing. 2009.

31. http://ecology.msu.montana.edu/labdsv/R

32. Colwell RK. Estimate S. Statistical estimation of species richness and shared species from samples. 2006.
33. Vivero JL, Kelbessa E, Demissew S. The Red list of Endemic trees and shrubs of Ethiopia and Eritrea. Fauna and Flora International, Cambridge, UK. 2005.

34. Soromessa T, Kelbessa E. Diversity and Endemicity of Chilimo Forest, Central Ethiopia. Bio Sci Disc. 2013;4(1):1-4.

35. Denu D. Floristic Composition and Ecological study of Bibita forest (Gura ferda), Southwest Ethiopia. M.Sc. thesis, AAU. 2006.

36. Kebede B. Floristic Composition and Structural Analysis of Gedo Dry Evergreen Montane Forest, West Shewa Zone of Oromia National Regional State, Ethiopia. M.Sc. thesis. AAU. 2010.

37. Lamprecht. Silvic culture in the tropics. Tropical forest ecosystems and their tree species possibilities and methods for their long-term utilization. $\mathrm{T}_{2}$-verlagsgesells chaft Gmbbh, RoBdort, Germany. 1989.

38. Lepš J, Šmilauer P. Multivariate Analysis of Ecological Data. Faculty of Biological Sciences, University of South Bohemia. 1999.

39. Seefeld K. Statistics Using R with Biological Examples, University of New Hampshire, Durham. Department of Mathematics \& Statistics. 2007.

40. Dufrêne M, Legendre P. Species assemblages and indicator species: the need for asymmetrical approach. Ecological Monographs. 1997;67(3):345-66.

41. Oksanen J. Multivariate Analysis in Ecology- Lecture Notes. University of Oulu David. 2004.

42. Woldemariam T. Floristic composition environmental factors characterizing coffee forests in southwest Ethiopia. Forest Ecol Manag. 2008;255:2138-50.

43. Biru M. An Ecological Study of Biteyu Forest, Gurage Zone, Southern Nation Nationalities Peoples Region. M.Sc. thesis, AAU. 2003.

44. Ayalew A. A composition and structural analysis of denkoro forest, south wello. M.Sc. thesis, AAU. 2003.

45. Bantiwalu S. Floristic composition, structure and regeneration status of plant species in sanka meda forest Arsi zone of Oromia region, southeast Ethiopia. M.Sc. thesis, AAU. 2010.

\section{"Correspondence to:}

Researcher and instructor

Biology Department

Wolkite University, Gubrei,

Wabe Bridge, Ethiopia

E-mail:msbd2006@gmail.com 